\title{
Two new species of Raphia (Palmae/Arecaceae) from Cameroon and Gabon
}

\author{
Suzanne Mogue Kamga', Raoul Niangadouma², Fred W. Stauffer ${ }^{3}$, \\ Bonaventure Sonké', Thomas L.P. Couvreur ${ }^{4,5}$
}

I Plant Systematic and Ecology Laboratory, Higher Teachers' Training College, University of Yaoundé I, P.O. Box 047, Yaoundé, Cameroon 2 National Herbarium of Gabon, R.D. 1135, Libreville, Gabon 3 Conservatoire et Jardin botaniques de la Ville de Genève, Laboratoire de systématique végétale et biodiversité, Université de Genève, Chambésy/GE, Switzerland 4 IRD, DIADE, Univ. Montpellier, Montpellier, France 5 Naturalis Biodiversity Centre, Botany Section, Darwinweg 2, 2333 CR Leiden, The Netherlands

Corresponding author: Thomas L.P. Couvreur (thomas.couvreur@ird.fr)

Academic editor: Y. Mutafchiev | Received 4 June 2018 | Accepted 17 October 2018 | Published 6 November 2018

Citation: Kamga SM, Niangadouma R, Stauffer FW, Sonké B, Couvreur TLP (2018) Two new species of Raphia (Palmae/Arecaceae) from Cameroon and Gabon. PhytoKeys 111: 17-30. https://doi.org/10.3897/phytokeys.111.27175

\begin{abstract}
Raphia (Arecaceae, Calamoideae) is the most diverse genus of African palms with around 20 species. Two new species from Cameroon and Gabon, Raphia gabonica Mogue, Sonké \& Couvreur, sp. nov. and Raphia zamiana Mogue, Sonké \& Couvreur, sp. nov. are described and illustrated. Their affinities are discussed and the conservation status of each species is assessed. For both species, distribution maps are provided. Raphia gabonica is restricted to two small populations from central Gabon, where it occurs on hillsides on tierra firme soil, and close to small streams. Its preliminary IUCN status is Endangered, being amongst the five most threatened palm species in Africa. Raphia gabonica potentially belongs to the moniliform section. Raphia zamiana is largely distributed from south Cameroon to south Gabon and is very common. It is also a multi-used palm, from which wine, grubs and construction material are extracted and sold. It generally occurs in large stands in a wide range of ecosystems such as swamps, coastal forests on partially inundated sandy soils and inundated savannahs. Its large stature, hard to access habitat (swamps) and abundant presence might have discouraged botanists to collect it until now. Raphia zamiana belongs to the taxonomically complex raphiate section.
\end{abstract}

\section{Keywords}

Cameroon, Gabon, Raphia, Arecaceae, Calamoideae, IUCN conservation status, new common species

Copyright Suzanne Mogue Kamga et al. This is an open access article distributed under the terms of the Creative Commons Attribution License (CC BY 4.0), which permits unrestricted use, distribution, and reproduction in any medium, provided the original author and source are credited. 


\section{Introduction}

Raphia (Raphiinae, Calamoideae) is the most species-rich genus of African palms with now 22 species currently recognised to date (Dransfield et al. 2008, Stauffer et al. 2014). In addition, most Raphia species are socio-economically important and widely used across tropical Africa (Tuley and Russell 1966, Balick and Beck 1990, Burkill 1997, Obahiagbon 2009). Despite their importance, the taxonomic understanding of this group remains very limited. This is mainly linked of their massive stature and hardto-access wild populations, often thriving in swampy and inundated areas, rendering botanical collections difficult. Based on the shape of the partial inflorescence, five sections were described by Otedoh (1982). Almost all species are restricted to tropical Africa (Stauffer et al. 2014), with a single species occurring in Madagascar ( $R$. farinifera (Gaertn.) Hylander) and one species (Raphia taedigera (Mart.) Mart.) occurring disjunctly in South and Central America (Dransfield et al. 2008). Most species occur in swampy environments forming large dense populations and only one species is so far known from tierra firme in forests (e.g. $R$. regalis Becc.). Raphia palms are acaulescent or more commonly with an aerial stem which can be solitary or clustered, bearing conspicuous fibres formed through the disintegration of leaf sheath margins (Otedoh 1982, Dransfield et al. 2008). Their leaves are pinnate and very large, up to $25 \mathrm{~m}$ in $R$. regalis (Hallé 1977, Dransfield et al. 2008), being amongst the longest in the plant kingdom. The species of Raphia are hapaxanthic (they die after flowering), monoecious, with basal female and apical male flowers on the same rachillae. The fruits are covered by imbricate scales typical of the Calamoideae subfamily genera (Dransfield et al. 2008).

The two new species reported here stem from extensive field work in Gabon, Cameroon, Republic of Congo and the Democratic Republic of Congo between September 2015 and February 2018.

\section{Material and methods}

Herbarium collections were made following methods described in Dransfield (1986). Measurements were taken from fresh and dry plant material collected in the field. Flowers were described following micro-morphology methods. Raphia collections from important international herbaria were studied (BR, FI, G, K, LBV, P, WAG, YA) (herbarium acronyms according to Thiers 2018) and online repositories (http://plants. jstor.org). The descriptions are based on herbarium specimens, field notes and spirit material when available. Unless otherwise stated, the dimensions mentioned for the various organs refer to dry material and the colours to fresh material. The conservation status was estimated for each species following the criteria and categories of the IUCN Red List version 3.1 (IUCN 2012). These were based on the geographical range estimated from herbarium specimens (Schatz 2002). The extent of occurrence (EOO) and the area of occupancy (AOO) were estimated using the online tool GeoCAT (Bachman et al. 2011). The minimum AOO was estimated based on a user defined grid cell of $2 \mathrm{~km}^{2}$. Phytogeographical considerations follow White $(1979,1983,1993)$. 


\section{Taxonomy}

Raphia gabonica Mogue, Sonké \& Couvreur, sp. nov.

urn:lsid:ipni.org:names:60477348-2

Figures 1, 2

Type. Gabon. Moyen Oogoué: $5 \mathrm{~km}$ from Alèmbé on national road in the direction to la Lope, 0.07916S, 11.00836E, 228 m a.s.l., 18 November 2015, Mogue K.S. 22 (holotype: WAG; isotypes: LBV, YA).

Diagnosis. Raphia gabonica closely resembles $R$. gentiliana by its solitary stem with curly fibres and the shape of the partial inflorescences. Raphia gabonica differs from $R$. gentiliana in being a mainly tierra firme species (vs. a swamp species), the shape of its fruits being globose, deltoid or ovoid (vs. ellipsoid) with 11 or 12 rows of scales (vs. 9-11) and a thick mesocarp measuring $>8 \mathrm{~mm}$.

Description. Stem 3-7 m tall, 20-30 cm in diameter, solitary; dead leaf sheaths persistent; trunk covered by fibres and old leaf sheaths; fibres formed through disintegration of leaf sheath margins ca. 1-2 $\mathrm{mm}$ in diameter, curly, dark brown to grey. Leaves 7 or 8, 8-13 $\mathrm{m}$ long in total, horizontal, then arching downwards towards the apex; sheath $80-140 \mathrm{~cm}$ long, $15-30 \mathrm{~cm}$ wide basally, channelled, smooth, margin fibrous, light brown with black and grey spots; petiole $1.7-4 \mathrm{~m}$ long, $7-10 \mathrm{~cm}$ in diameter basally, channelled, smooth, brown with dark and grey spots, green at younger stages; rachis 5-7 m long, channelled basally and keeled towards the apex, smooth, no spines on keel, light brown to brown, spotted black and grey; pinnae 170-195 per side, irregularly arranged in 4 planes, arching downwards towards the apex, extreme basal pinnae $55-70 \mathrm{~cm}$ long, 1.2-1.3 wide, filiform, middle pinnae $1.10-1.20 \mathrm{~m}$ long, $4.5-5 \mathrm{~cm}$ wide, linear, apical pinnae $9-23 \mathrm{~cm}$ long, $0.6-2.4 \mathrm{~cm}$ wide, linear, midrib prominent adaxially, brown spines along pinnae midrib and margins, older pinnae bearing spines more basally, younger ones throughout the pinnae, pinnae adaxial surface dark green, abaxial surface waxy green. Leaves next to inflorescence reduced with split sheaths. Inflorescences 5, pendulous, 1.2-1.8 m long, $9-10 \mathrm{~cm}$ (young) to $30-35 \mathrm{~cm}$ (mature) in diameter at base (including rachillae); light brown to brown; prophyll tubular, bearing 2 keels merging to form a pointed beak; peduncle 20-25 cm long, 7-8 cm in diameter, dorsi-ventrally compressed, smooth dark brown abaxially; penduncular bracts 8-20, tubular with triangular apices, smooth, dark brown abaxially; rachis $1.40-1.60 \mathrm{~m}$ long, bearing numerous bracts rarely empty, 50-70 first order rachillae, moniliform in shape, circular, alternating in 2 rows on each side of the rachis, smooth, prophyllar bract at the base of first order rachillae, tubular, bearing 2 keels at the side, smooth; basal first order rachillae $30-40 \mathrm{~m}$ long, $1.5-2 \mathrm{~cm}$ in diameter excluding rachillae, $25-30 \mathrm{~cm}$ including second order rachillae, bud flattened; prophyllar bract at the base bearing 2 keels on both sides, other bracts bearing flowers, rarely empty; second order rachillae ca. 38 per side, basal second order rachillae $15-19 \mathrm{~cm}$ long, $0.3-0.5 \mathrm{~cm}$ in diameter, middle second order rachillae 9-12 cm long, $0.4-0.5 \mathrm{~cm}$ in diameter, apical second order rachillae $2.5-5 \mathrm{~cm}$ long, $0.3-0.4 \mathrm{~cm}$ in diameter, circular, alternating in 2 rows on each side of first order ra- 
chillae, bud 1.5-1.7 cm long, flattened, smooth; middle first order rachillae 27-30 $\mathrm{cm}$ long, $1.5-2 \mathrm{~cm}$ in diameter excluding rachillae, $20-22 \mathrm{~cm}$ including second order rachillae, bud flattened; prophyllar bract at the base bearing 2 keels on both sides, other bracts bearing flowers, rarely empty; second order rachillae ca. 33 per side, basal second order rachillae $14-15 \mathrm{~cm}$ long, ca. $0.5 \mathrm{~cm}$ in diameter, middle second order rachillae $8.5-9 \mathrm{~cm}$ long, ca. $0.5 \mathrm{~cm}$ in diameter, apical second order rachillae 2.5-3 $\mathrm{cm}$ long, ca. $0.5 \mathrm{~cm}$ in diameter, circular, alternating in 2 rows on each side of first order rachillae, bud flattened, smooth; apical first order rachillae: $17-20 \mathrm{~cm}$ long, $1-1.5 \mathrm{~cm}$ in diameter excluding rachillae, $7-10 \mathrm{~cm}$ including second order rachillae, bud flattened; prophyllar bract at the base bearing 2 keels on both sides, other bracts bearing flowers rarely empty; second order rachillae 20 per side, basal second order rachillae $4-7 \mathrm{~cm}$ long, $0.2-0.3 \mathrm{~cm}$ in diameter, middle second order rachillae $4-5 \mathrm{~cm}$ long, $0.2-0.3 \mathrm{~cm}$ in diameter, apical second order rachillae $2.5-3.5 \mathrm{~cm}$ long, $0.2-0.3$ $\mathrm{cm}$ in diameter, circular, alternating in 2 rows on each side of first order rachillae, bud flattened, smooth, light brown. Flowers: only very old or very young flowers observed, solitary, exerted, arranged in one row (sometimes two) on each side of second order rachillae, staminate flowers distal, pistillate flowers basal, stamens 6. Fruit. ca. 4 $\mathrm{cm}$ long, $3.5 \mathrm{~cm}$ in diameter, beak $0.5 \mathrm{~cm}$; globose, deltoid or ovoid; scales arranged in 11 or 12 rows, shallowly furrowed, dark green to brown when young, turning orange-red at maturity; mesocarp ca. $0.8 \mathrm{~cm}$ thick, yellow; seeds $1-3$, circular covered in a white coating.

Ecology. Raphia gabonica occurs in lowland rain forests, growing on hill sides on tierra firme and also near streams. Seen occurring together with Sclerosperma mannii H.Wendl. and Elaeis guineensis A.Chev.

Distribution. Lower Guinea subcentre of endemism (White 1979). Raphia gabonica is restricted to the northern part of the Ngounié region in Gabon occurring in very small populations in forests. Altitude 76-228 m (Fig. 3).

Preliminary conservation status. Endangered: EN B2ab(ii): Raphia gabonica is a rare species collected from two close locations in central Gabon (Fig. 3). Its minimal area of occupancy (AOO) is estimated to be $8 \mathrm{~km}^{2}$ (within the limits for Critically Endangered status under criterion B2). To date, two locations are known within the limits of the Endangered status. Both collections were made recently (2015) along important road axes (e.g. Nationale 1) and in unprotected areas (Fig. 3). For each location, several individuals were seen indicating no immediate threat. However, we project that the ongoing loss of its natural habitat linked to increased human activity will induce an important decline of its EOO and AOO. Raphia gabonica is therefore assigned a preliminary status of EN B2ab(ii), joining the almost $5 \%$ of continental African palms under this category (Cosiaux et al. 2018)

Uses. No uses have been reported for this species.

Notes. Raphia gabonica appears to belong to the moniliform section of Otedoh (1982) linked to the shape of its partial inflorescences. However, the solitary trunk with curly fibres could also suggest a resemblance to species within the temulentae section (e.g. Raphia hookeri G.Mann \& H.Wendl. or R. sese De Wild.). 


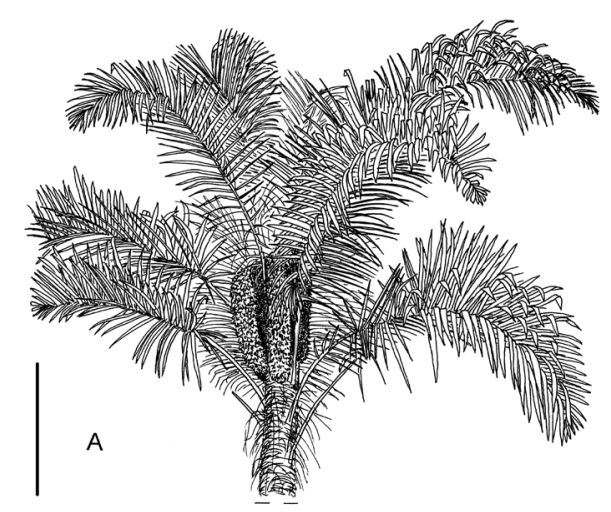

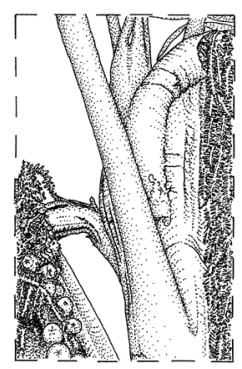

D

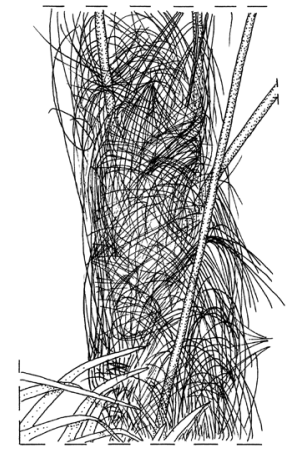

B
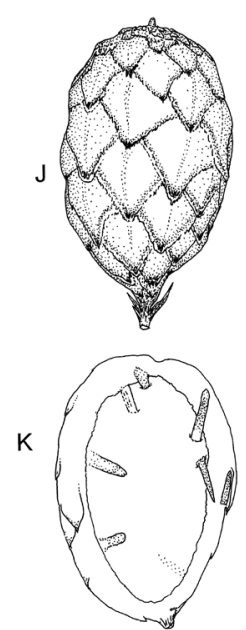
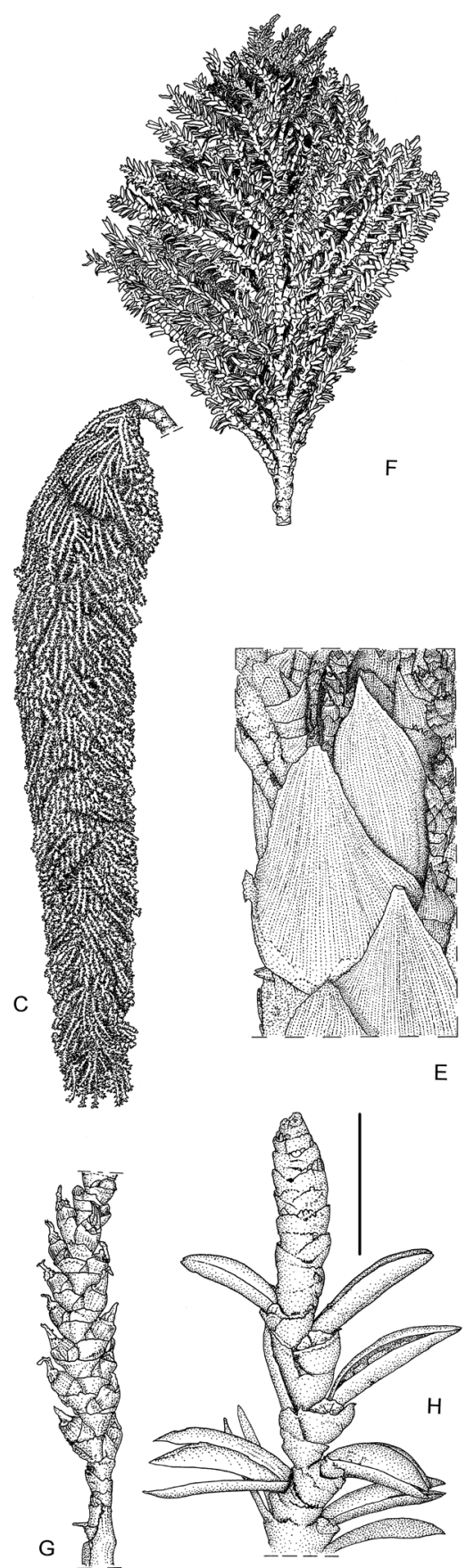

Figure I. Raphia gabonica, illustrations. A Habit $(\mathrm{bar}=1 \mathrm{~m})$ B Details of trunk - notice curly fibres C Detail of full inflorescence D Detail of base of inflorescence $\mathbf{E}$ Penduncular bracts $\mathbf{F}$ Partial inflorescence with old flowers $\mathbf{G}$ Detail of basal part of rachillae with old female flower $\mathbf{H}$ Detail of apical part of rachillae with old male flowers (Scale bar: $1 \mathrm{~cm}$ ) I Partial inflorescence with fruits J Fruit K Longitudinal section of fruit. Drawings based on A from Mogue 22 B-J Mogue 23. Drawings by Hans de Vries. 


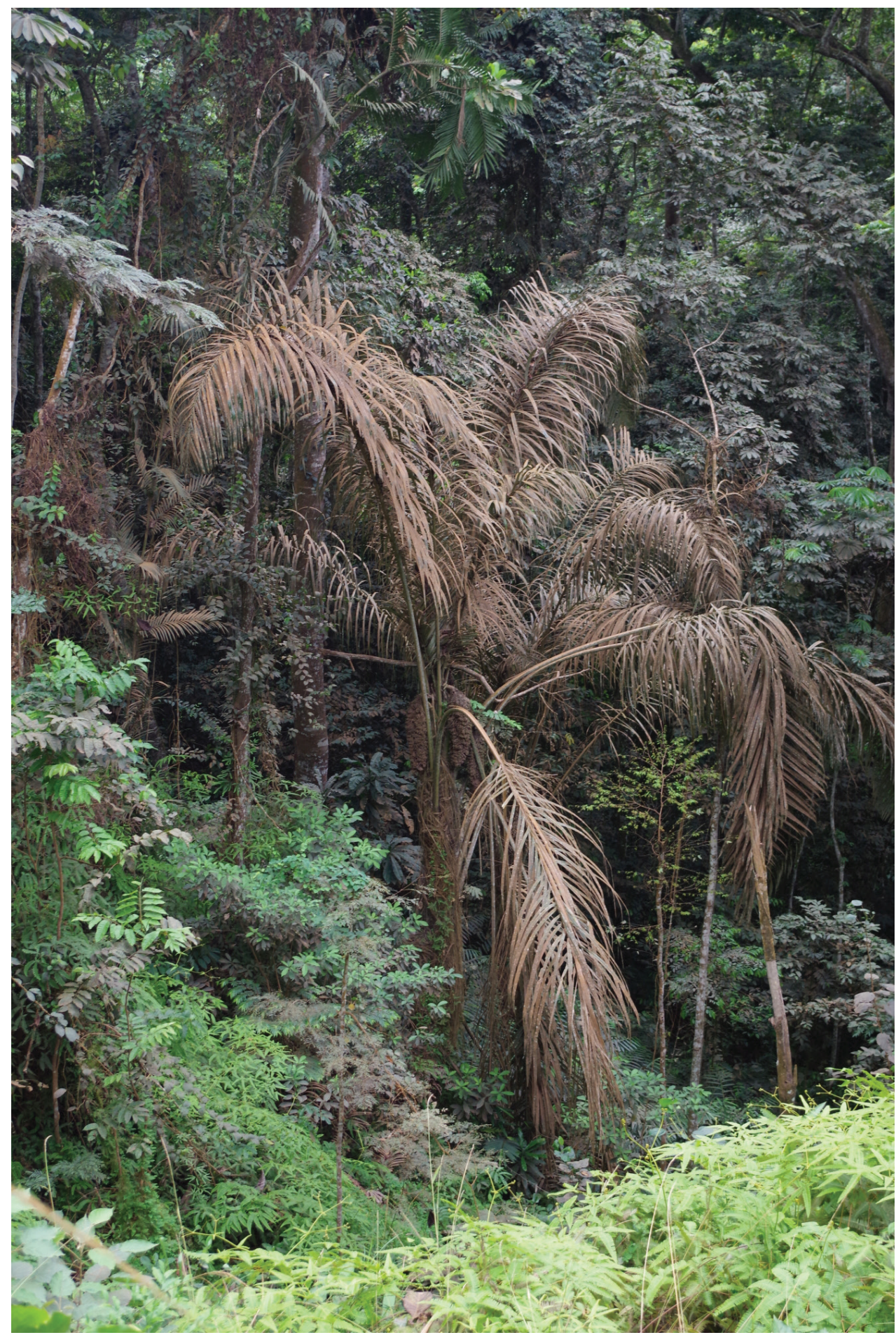

Figure 2. Raphia gabonica in natural habitat (Alèmbé, Gabon). Notice dry land habitat, not growing in colonies, single stem with curly fibres and long pendulous inflorescences. Photo: Thomas L.P. Couvreur. 


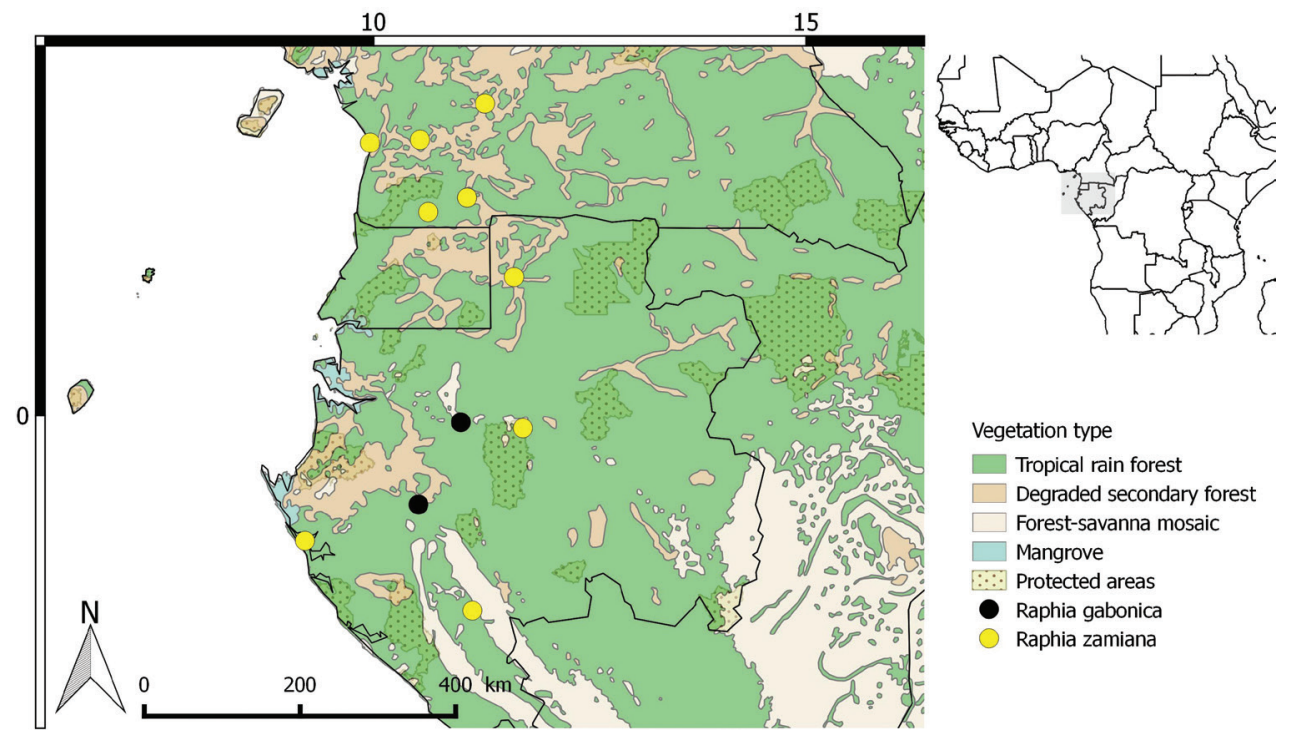

Figure 3. Distribution of Raphia gabonica and $R$. zamiana.

Additional specimen examined. GABON. Ngounié: Zamata village along national road N1, 1.03044S, 10.51881E, 76 m a.s.l., 19 Nov 2015, Mogue K.S. 23 (LBV, WAG,).

\section{Raphia zamiana Mogue, Sonké \& Couvreur, sp. nov.} urn:Isid:ipni.org:names:60477349-2

Figures 4, 5

Type. Cameroon: South Region: Vallée du Ntem, Nseng avion forest, Fondation agricole Samuel Menye, $1.5 \mathrm{~km}$ from Ma'an in the direction of the Ntem river, $2.34805 \mathrm{~N}$, 10.63054E, 513 m a.s.l., 25 February 2018, Mogue K. S. 44 (holotype: WAG; isotypes: K, YA).

Diagnosis. Raphia zamiana is morphologically most similar to $R$. monbuttorum in their clustering habitat and straight fibres covering the trunk. Raphia zamiana differs from $R$. monbuttorum by the size of its stout and stiff rachillae with apical second order rachillae measuring $1 \mathrm{~cm}$ in diameter versus less than $1 \mathrm{~cm}$ in $R$. monbuttorum. The inflorescences of $R$. zamiana are pendulous even from the early stage of development as opposed to the semi obtuse erect position in $R$. monbuttorum.

Description. Stem 3-8 m tall, 30-40 cm in diameter, clustering; dead leaf sheaths persistent, trunk hidden in dead leaves and fibres; fibres formed through disintegration of the leaf sheath, ca. $1 \mathrm{~cm}$ in diameter, straight with pointed tips, brown to black. Leaves 10-12, 12-21 m long in total, horizontal and then arched downwards towards apex; sheath 90-150 cm long, channelled, smooth, margin fibrous, orange-yellow, spotted with black, white and or grey dots; petiole 4-11 m long, 5-35 cm in diameter towards the base, channelled basally and elliptic apically, smooth, green, spotted with 
dark and grey; rachis $7-13 \mathrm{~m}$ long, $10-11 \mathrm{~cm}$ in diameter, elliptic basally and keeled towards the apex, smooth abaxially, spiny adaxially (spines on keel), light green to green; pinnae 147-268 per side, irregularly arranged in 4 planes, arching downwards towards the apex, pinnae adaxial surface green, abaxial surface waxy green; extreme basal pinnae $0.80-1.26 \mathrm{~m}$ long, 7-30 mm wide, filiform, middle pinnae 1.50-1.90 $\mathrm{m}$ long, 5-9 cm wide, linear, apical pinnae $20-72 \mathrm{~cm}$ long, $1.5-3.6 \mathrm{~cm}$ wide, linear, midrib prominent adaxially, spines along pinnae midrib and margins, brown to black. Leaves subtending inflorescence reduced (1.20-1.40 m long).

Inflorescences 3 or 4, pendulous, $1.55-2.80 \mathrm{~m}$ long in total, $17-44 \mathrm{~cm}$ (mature) in diameter at base (including rachillae); young inflorescences light green to purple green, older ones light brown to grey-brown. prophyll 18-20 cm long, $13.7 \mathrm{~cm}$ diameter, tubular, bearing 2 keels merging to form a pointed beak; peduncle $26-30 \mathrm{~cm}$ long, 10-13.5 cm diameter, dorsi-ventrally compressed, smooth; penduncular bracts several, tubular, with triangular apices, smooth, dark brown abaxially; rachis $1.25-2.60 \mathrm{~m}$ long, bearing numerous bracts rarely empty, 50-70 first order rachillae, raphiate shape, dorsi-ventrally compressed, alternating in 2 rows on each side of the rachis, smooth; prophyllar bract found at the base of first order rachillae, tubular, bearing 2 keels at the sides, smooth; basal first order rachillae $0.54-1.05 \mathrm{~m}$ long, $4.5-7 \mathrm{~cm}$ in diameter excluding rachillae, ca. $14 \mathrm{~cm}$ in diameter including rachillae, bud flattened; prophyllar bract bearing 2 keels on both sides, subsequent bracts bearing flowers, rarely empty; second order rachillae 48-65, basal second order rachillae $23-35 \mathrm{~cm}$ long, $2-2.5 \mathrm{~cm}$ in diameter; middle second order rachillae $15-27 \mathrm{~cm}$ long, $2 \mathrm{~cm}$ in diameter; apical second order rachillae $9.5-15 \mathrm{~cm}$ long, $1.5-1.6 \mathrm{~cm}$ in diameter, dorsi-ventrally compressed, alternating in 2 rows on each side of first order rachillae, bud flattened, smooth; middle first order rachillae 39-45 cm long, 3-4 cm in diameter excluding rachillae, $12 \mathrm{~cm}$ in diameter including second order rachillae, bud flattened; prophyllar bract at the base bearing 2 keels on both sides, subsequent bracts bearing flowers rarely empty; second order rachillae 32-50, basal second order rachillae $16 \mathrm{~cm}$ long, $1.5 \mathrm{~cm}$ in diameter, middle second order rachillae $13 \mathrm{~cm}$ long, $1.2 \mathrm{~cm}$ in diameter; apical second order rachillae ca. $10 \mathrm{~cm}$ long, ca. $1 \mathrm{~cm}$ in diameter, dorsi-ventrally compressed, alternating in 2 rows on each side of first order rachillae, bud flattened, smooth; apical first order rachillae $25-27 \mathrm{~cm}$ long, ca. $2.5 \mathrm{~cm}$ in diameter excluding rachillae, $12 \mathrm{~cm}$ in diameter including second order rachillae, bud flattened; prophyllar bract at the base bearing 2 keels on both sides; second order rachillae 12-30, basal second order rachillae ca. $10 \mathrm{~cm}$ long, ca. $1 \mathrm{~cm}$ in diameter; middle second order rachillae ca. $8 \mathrm{~cm}$ long, 1 $\mathrm{cm}$ in diameter; apical second order rachillae ca. $6 \mathrm{~cm}$ long, ca. $1 \mathrm{~cm}$ in diameter, dorsiventrally compressed, alternating in 2 rows on each side of first order rachillae, bud flattened, smooth; second order rachillae sometimes three times the usual size (more than $25 \mathrm{~cm}$ long, $2.5 \mathrm{~cm}$ wide at the apex). Inflorescence bud ca. $5 \mathrm{~cm}$ long, ca. $1.2 \mathrm{~cm}$ wide, buds of basal and medial first order rachillae sometimes elongated. Flowers solitary, exerted, inserted in two rows on each side of second order rachillae, staminate flowers distal, pistillate flowers basal. Staminate flower 13-18.5 mm long, 7.5-11.5 mm wide, stalk ca. $1 \mathrm{~mm}$ long; subtending bracteole $4.5-13.5 \mathrm{~mm}$ long, 7-11.5 mm wide, 

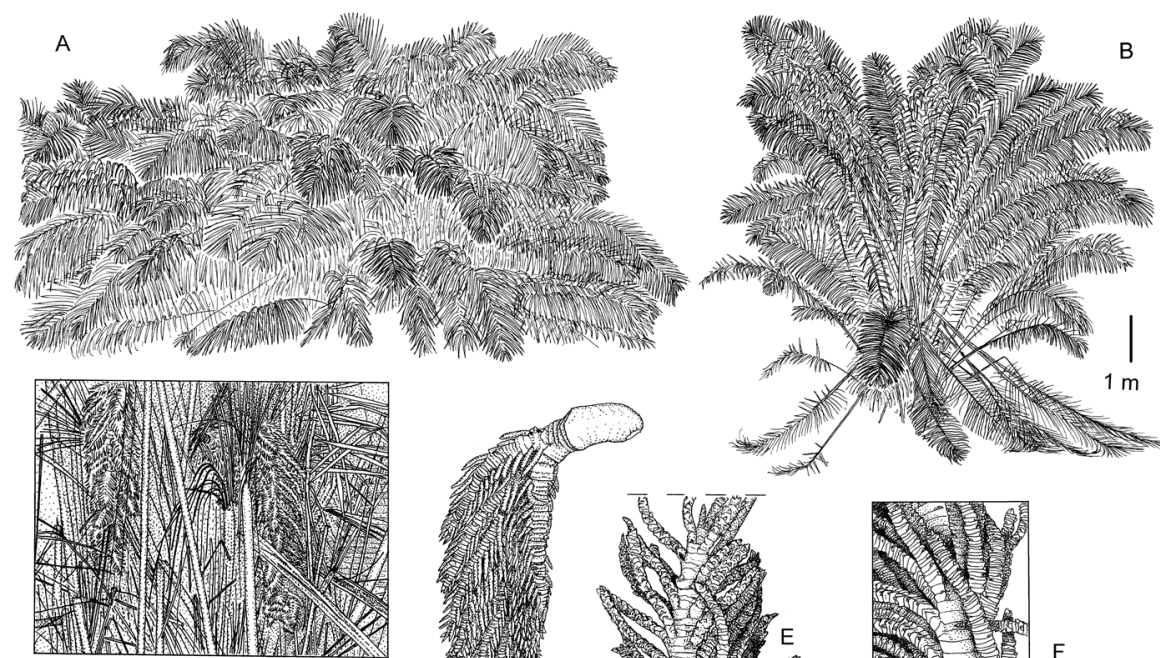

C
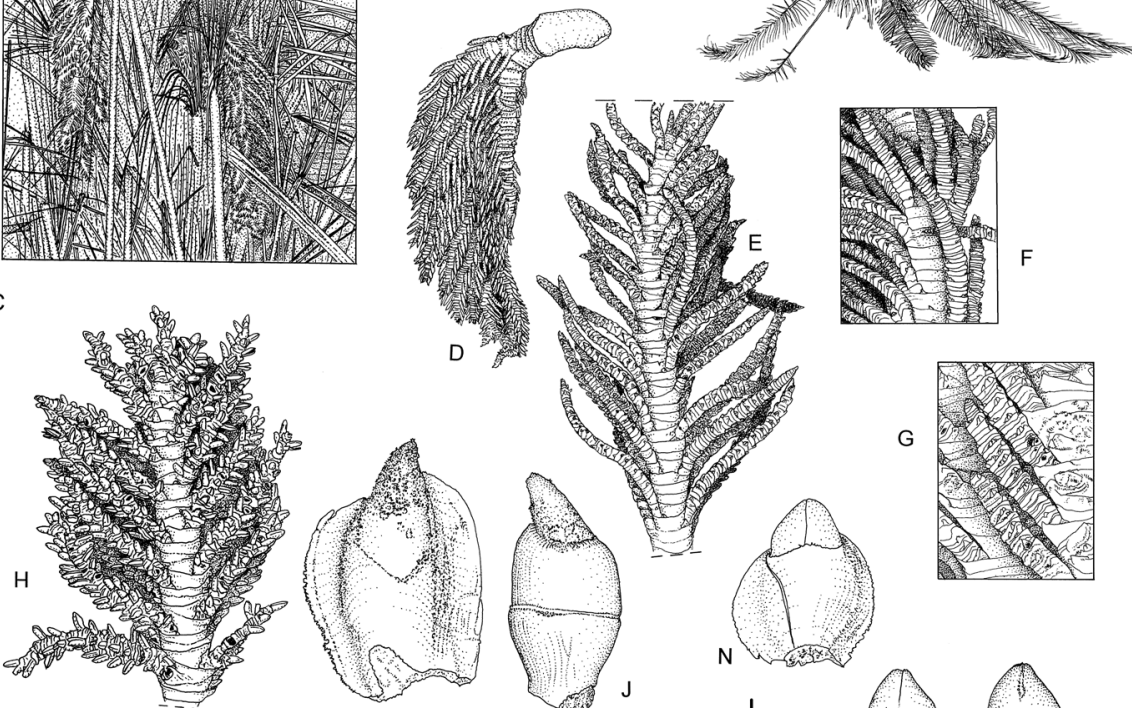

$\mathrm{G}$
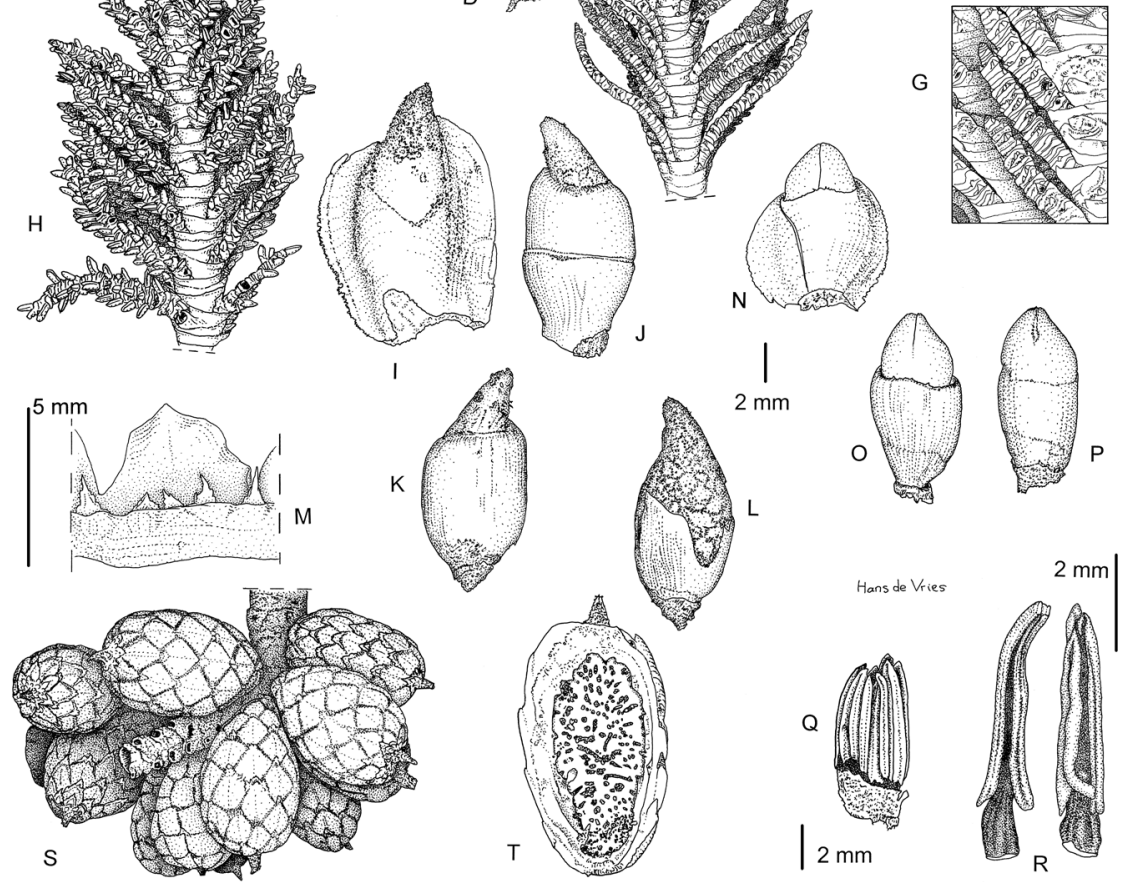

\section{L}

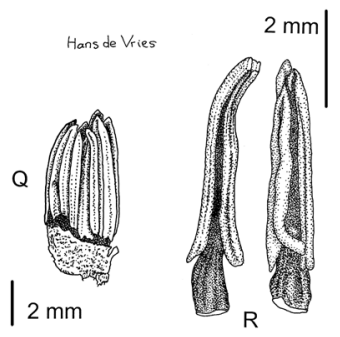

Figure 4. Raphia zamiana, illustrations. A Habit in savannah B Habitat in forest, trunk not visible C Detail of the trunk, with inflorescences and straight fibres D Inflorescence E Partial inflorescence, young $\mathbf{F}$ Detail of rachillae $\mathbf{G}$ Detail of basal part of $2^{\text {nd }}$ order rachillae, showing small rachillae bracts encircling young flowers $\mathbf{H}$ Detail of partial inflorescence $(\times 5) \mathbf{I}$ Female flower $\times 5 \mathbf{J}$ Female inner bract $\times 5 \mathbf{K}$ Female calyx $\times 5 \mathbf{L}$ Female corolla $\times 5 \mathbf{M}$ Detail of staminodial ring and staminodes $\mathbf{N}$ Male flower $\times 5 \mathbf{O}$ Male calyx $\times 5 \mathbf{P}$ Male corolla $\times 5 \mathbf{Q}$ male stamens $\times 6 \mathbf{R}$ Detail of stamen of male flower $\times 12 \mathbf{S}$ Infructescence T Fruit, longitudinal section. Drawings based on: A Couvreur 1122 B-D, S, T Mogue; 17 E-R Mogue 44. Drawings by Hans de Vries. 
tubular, bicarinate, margins entire, smooth, with a conspicuous wide apical slit on one side, displaying conspicuous longitudinal veins on the outer side, bracteole completely covering the calyx; calyx 5-11.5 mm long, 5-7 mm wide, fused >2/3 of its length, tubular, bearing 2 or 3 shallow lobes, margins entire to slightly rough, smooth; conspicuous longitudinal veins on outer side; corolla 3, 8.5-15(-20) $\mathrm{mm}$ long, 4-6 mm wide, basally connate for $1 / 3$ of their length, oblong, apex slightly blunt to acuminate, margins entire, smooth, stiff, displaying a conspicuous longitudinal venation on the inner side; stamens $11-18$, filaments 1-4(-6) mm long, 1-1.7 mm wide, free, basally adnate to the petals for 1-2 mm, cream white to pale pink; anthers $4-8.8 \mathrm{~mm}$ long, $1-1.5 \mathrm{~mm}$ wide, sagittate-elongate, medifixed, pale yellow; pistillode absent. Pistillate flowers 15-25 mm long, 10-13 mm wide; outer subtending bracteole 12-19 mm long, 10$13 \mathrm{~mm}$ wide, tubular, bicarinate, margins entire, with one wide apical slit, smooth; inner subtending bracteole 5-9 $\mathrm{mm}$ long, tubular, margins entire, one side longer, smooth, sometimes tearing; calyx $8.5-16 \mathrm{~mm}$ long, fused $>2 / 3$ of its length, tubular, 3 shallow lobes or the latter rarely absent, margins entire, smooth, with longitudinal veins conspicuous on both sides; corolla 5-8 mm long, fused, 3 lobes with margins serrated, lobes sometimes slightly acuminate, margins entire, smooth, conspicuous longitudinal veins; staminodial ring with 17-19 fused staminodes, 2-5 mm long, adnate to petals for 1-4 mm; anthers sagittate, 0.5-1 mm long; gynoecium 11-18 mm long, 5-6 mm wide, ovary 9-12 mm, 5-6 mm wide, ovate to oblong, completely covered with scales, developing at $3 / 4$ height of the gynoecium, larger scales at mid portion to base; style absent or very short; stigma ca. $1 \mathrm{~mm}$ long, papillae not observed but hairlike prolongations present on stigma. Fruits $4-8.7 \mathrm{~cm}$ long, $3.5-4.7 \mathrm{~cm}$ wide, beak $0.5-0.9 \mathrm{~cm}$ long; oblong, scales arranged in 11 or 12 rows, length of scale $16-20 \mathrm{~mm}$, width of scale 15-20 mm, diamond shaped, apex texture rough, shallowly furrowed, green, beak pointed, inflated in the middle; mesocarp yellow when young, orange yellow when mature; seed 1, oblong, with ruminations.

Ecology. Raphia zamiana is an Atlantic central African rain forest species, endemic to lower Guinea. It appears to have a wide ecological amplitude, growing in rain forest swamps on periodically inundated soils, in coastal forests on inundated sandy soils or in open vegetation like savannahs associated with inundated soils (e.g. Lope National Park, Gabon, Figs 3, 5C). It is generally abundant forming large dense almost monodominant stands. It has been recorded growing sympatrically with $R$. hookeri and $S$. mannii.

Distribution. Lower Guinea subcentre of endemism (White 1979). Raphia zamiana occurs in southern Cameroon (Central and South regions) and western Gabon. It is probably also common in Equatorial Guinea although no collections have been made yet. Altitude: 0-700 m (Fig. 3).

Preliminary conservation status. Least Concern. The extent of occurrence of Raphia zamiana is estimated to be $128,243,063 \mathrm{~km}^{2}$ (far exceeding the $20,000 \mathrm{~km}^{2}$ upper limit for Vulnerable status under criterion B1) and the area of occupancy is estimated to be $36,000 \mathrm{~km}^{2}$ (far exceeding the 2,000 $\mathrm{km}^{2}$ upper limit for Vulnerable status under criterion B2). Moreover, this species is known from 9 locations, the upper limit for sub criterion a- of criterion B2 for the Vulnerable status. However, Raphia zamiana 

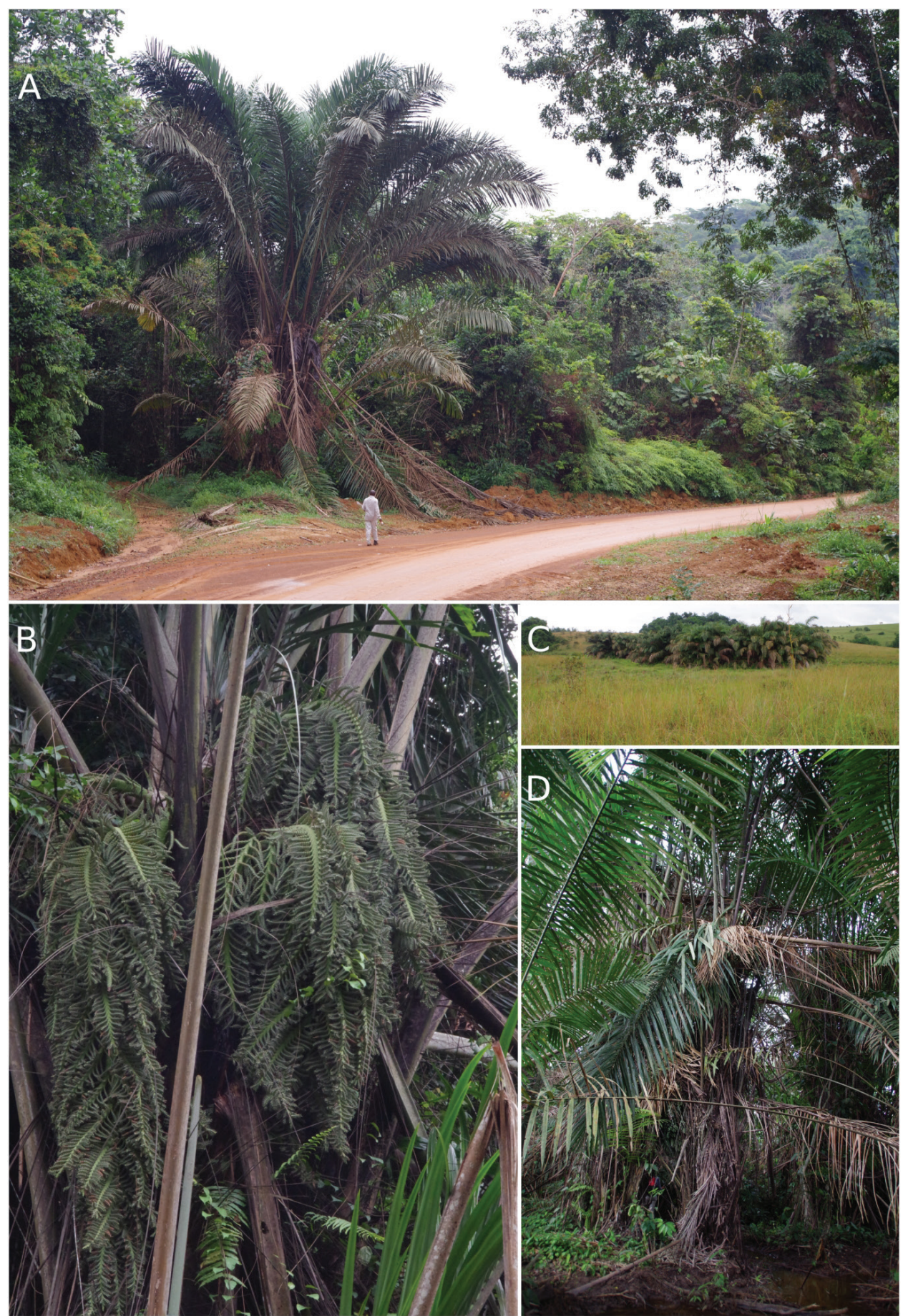

Figure 5. Raphia zamiana. A Habitat along the road, with Raoul Niangadouma for scale (Oyem, Gabon) B Close-up of pendulous and "raphiate" type partial inflorescence (coastal forests near Kribi, Cameroon) C Habitat in the savannahs of Lopé National Park, Gabon D Habitat in swamp (Mảan, Cameroon). Photos: Thomas L.P. Couvreur. 
is a widespread and common species in its area of occurrence. It is very common along road sides and is abundant growing in dense colonies. To date, it has not been collected within a protected area, but populations were seen in Campo National Park (Cameroon). Incredibly, its first collection dates to 2012. Botanists might have confused it with the well-known and widespread species Raphia hookeri (although both species are very different in their morphology). Given that collecting Raphias is a hard task because of their massive stature (Dransfield 1986), it was simply omitted. Populations are affected by road building and the drying of swamps for bridges, but these only impact a small number of individuals. Raphia zamiana is therefore assigned a preliminary status of LC, joining most continental African palm species (Cosiaux et al. 2018).

Etymology. The name of this species is derived from its vernacular name in Beti (south Cameroon, north Gabon): Zam.

Uses. This palm is massive thus providing large amounts of thatching material. Its petiole and rachis commonly referred to as 'bamboo' are used for house construction, beds, chairs, baskets and mats. These are generally sold along the roads in south Cameroon. In Gabon, its fruits are sold in markets. These are boiled and said to cure hypertension and diabetes. Finally, this species is also used for wine tapping and as a source of grubs.

Vernacular names. Zam (Beti).

Notes. Raphia zamiana belongs to the raphiate section (Otedoh 1982). It closely resembles $R$. monbuttorum Drude and $R$. laurentii De Wild. in the morphology of their trunks being clustered and covered with straight fibres. However, it is very distinct by having a pendulous inflorescence bearing stout, stiff and straight rachillae. The inflorescences of $R$. monbuttorum and $R$. laurentii usually hang at an obtuse angle especially during the young stages of development, becoming pendulous only when brought down by the weight of fruits. Young, recently developing inflorescences are grey-blue turning green later on.

Raphia zamiana is a very conspicuous palm in southern Cameroon and eastern Gabon, being common along roads and in swamps. In addition, we report several important uses, being one of the most useful Raphias (Mogue, personal observation). However, up to now, it remained uncollected, stressing once again that new species well known to local people have yet to be scientifically discovered and described. A similar situation was recorded for the Vietnamese endemic palm Licuala centralis (Henderson et al. 2008). This palm was well known and used to make local hats, but was only scientifically described in 2008.

Additional specimen examined. CAMEROON. Central Region. near Ebolbom village, $3 \mathrm{~km}$ east of Ngoumou, $2 \mathrm{~km}$ northwest of Otélé, 3.599720N, 11.287700E, 700 m a.s.l., 2 May 2013, Couvreur T.L.P. 427 (WAG, YA). South Region: Mvila, Biyeyem, 2.514020N, 11.081930E, 573 m a.s.l., 19 Sep 2015, Mogue K.S. 15, (WAG, YA); Mvila, Biyeyem, 2.514020N, 11.081930E, 573 m a.s.l., 19 Sep 2015, Mogue K.S. 16 (WAG, YA); mountain chain Ngovoyang, $1.5 \mathrm{~km}$ in forest from Bikiliki village situated between Bipindi and Lolodorf, 3.181570N, 10.536960E, $460 \mathrm{~m}$ a.s.l., 17 Feb 2012, Couvreur, T.L.P.392 (WAG, YA); About 20 km N from Kribi, 3 km N 
of Longji, N7 road towards Edea, 3.146810N, 9.959510E, 0 m a.s.l., 27 Feb 2018, Mogue K.S. 45 (WAG, YA).

GABON. Woleu-Ntem: Oyem, 2-3 km from main road in the direction of Konosoville, 01.59849N, 011.62298E, 651 m a.s.l., 12 Nov 2015, Mogue K.S. 17 (LBV, WAG, YA); Ogooué-Ivindo: $180 \mathrm{~km}$ on main road from Lastoursville to Lopé, 0.147300S, 11.726011E, 280 m a.s.l., 9 Jun 2016, Couvreur T.L.P. 1122 (LBV,WAG, YA). Ogooué-Maritime: Lagune de Fernan Vaz. Koundakoua, 1.4487220S, 9.2066110E, 3 m a.s.l., 20 Nov 2016, Bidault E. 2722 (BR, BRLU, LBV, MO, P, WAG). Ngounié: Mouila, $19 \mathrm{~km}$ from national road, 2.254280S, 11.142840E, 133 m a.s.l., 20 Nov 2015, Mogue K.S. 24 (LBV, WAG, YA).

\section{Acknowledgements}

We are very grateful to Richard Oslisly and his keen naturalist eye for providing detailed locality information about a "weird tierra firme Raphia" near Lope which led to the discovery of Raphia gabonica. We are grateful to the Centre National de la Recherche Scientifique et Technique (CENAREST) in Gabon and the Agence National des Parques Nationaux (ANPN) for delivering the necessary research permits for our field work in Gabon in 2015 and 2016 (permits AR0020/16; AR0036/15 (CENAREST) and AE16014 (ANPN)). Prof. Paul Henri Bourobou Bourobou is thanked for his assistance in obtaining these research permits. Fieldwork in Cameroon was undertaken under the "accord cadre de cooperation" between the IRD and Ministère de la Recherche Scientifique et Technique (MINRESI). This study was supported by Agropolis Fondation (RAPHIA project) under the reference ID 1403-026 through the "Investissements d'avenir » program (Labex Agro:ANR-10-LABX-0001-01), under the frame of I-SITE MUSE (ANR-16-IDEX-0006) and the Agence Nationale de la Recherche (grant number ANR-15-CE02-0002-01), both to TLPC; and an International Palm Society (IPS) grant to SMK. We are grateful to Larry Noblick for commenting on an earlier version. We thank Hans de Vries for his high quality drawings. Finally, we are grateful to Jean Grégoire (aka Petit Jean) Kayoum for his driving skills and help in the field when in Gabon and Narcisse Kandem for field assistance in Cameroon.

\section{References}

Bachman S, Moat J, Hill AW, de la Torre J, Scott B (2011) Supporting Red List threat assessments with GeoCAT: Geospatial conservation assessment tool. ZooKeys 150: 117-126. https://doi.org/10.3897/zookeys.150.2109

Balick MJ, Beck HT (1990) Useful Palms of the World. A synoptic bibliography. Columbia, University Press, New York, 274 pp.

Burkill HM (1997) The Useful Plants of West Tropical Africa, (Families M-R), Vol. 4 (2 ${ }^{\text {nd }}$ edn). Royal Botanic Gardens, Kew, 969 pp. 
Cosiaux A, Gardiner LM, Stauffer FW, Bachman SP, Sonké B, Baker WJ, Couvreur TLP (2018) Low extinction risk for an important plant resource: Conservation assessments of continental African palms (Arecaceae/Palmae). Biological Conservation 221: 323-333. https:// doi.org/10.1016/j.biocon.2018.02.025

Dransfield J (1986) A guide to collecting palms. Annals of the Missouri Botanical Garden 73(1): 166-176. https://doi.org/10.2307/2399148

Dransfield J, Uhl NW, Asmussen CB, Baker WJ, Harley MM, Lewis CE (2008) Genera Palmarum: The Evolution and Classification of Palms. Kew Publishing, 732 pp.

Hallé F (1977) The longest leaf in palms? Principes 21: 18.

Henderson A, Ban NK, Dung NQ (2008) New species of Licuala (Palmae) from Vietnam. Palms 52: 141-154.

IUCN (2012) IUCN Red List Categories and Criteria: Version 3.1. (2 $2^{\text {nd }}$ edn). IUCN Gland and Cambridge.

Obahiagbon FI (2009) A review of the origin, morphology, cultivation, economic products, health and physiological implications of Raphia palm. African Journal of Food Science 3: 447-453.

Otedoh M (1982) A revision of the genus Raphia Beauv. (Palmae). Journal of the Nigerian Institute for Oil Palm Research 6: 145-189.

Schatz GE (2002) Taxonomy and herbaria in service of plant conservation: Lessons from Madagascar's endemic families. Annals of the Missouri Botanical Garden 89(2): 145-152. https://doi.org/10.2307/3298559

Stauffer FW, Ouattara D, Stork AL (2014) Palmae. In: Lebrun J-P, Stork AL (Eds) Tropical African Flowering Plants: Monocotyledons 2, Volume 8. Conservatoire et Jardin botaniques de la Ville de Genève, Switzerland, Genève, 326-354.

Thiers B (2018) Index Herbariorum: A global directory of public herbaria and associated staff. New York Botanical Garden's Virtual Herbarium. http://sweetgum.nybg.org/science/ih/

Tuley P, Russell T (1966) The Raphia palms reviewed. Nigerian Field 31: 54-65.

White F (1979) The Guineo-Congolian Region and its relationship to other phytochoria. Bulletin du Jardin Botanique National de Belgique 49(1/2): 11-55. https://doi. org/10.2307/3667815

White F (1983) The vegetation of Africa, a descriptive memoir to accompany the UNESCO/ AETFAT/UNSO vegetation map of Africa. United Nations Educational, Paris, 356 pp.

White F (1993) The AETFAT chorological classification of Africa: History, methods and applications. Bulletin du Jardin Botanique National de Belgique 62(1/4): 225-281. https:// doi.org/10.2307/3668279 